\title{
Perceived Determinants of Leadership Position in Sports Management by Gender in Ebonyi State, Nigeria
}

\author{
Dr Patricia Ngwakwe', Nwamaka Agbe Egba ${ }^{2}$, Dr Emeka U. Mong ${ }^{3}$ \\ ${ }^{1,2,3}$ Department of Human Kinetics and Health Education, Ebonyi State University, PMB 053 Abakaliki, Nigeria
}

\begin{abstract}
This study investigated perceived determinants of leadership positions in Sports Management by gender in Ebonyi State, Nigeria. Descriptive survey research design was used. All the 410 staff members of Ebonyi State Sports Council and Ministry of Youths and Sports were used for the study. A self-developed instrument titled: Leadership scale questionnaire (LSQ) was used to collect data for the study. The instrument had a reliability coefficient of $r=0.898$. The data were analysed using mean, standard deviation and $t$-test, with level of significant set at 0.05 . The result showed that there was a significant difference in the perception of gender, and no significant difference in the perception of age, level of education and work experience as determinants of leadership positions in sports management by gender in Ebonyi State, Nigeria. The study therefore, recommended that Government, sports bodies, and organization should include women in the policy and decision making bodies of sports in order to reduce male dominance.
\end{abstract}

Keywords: Sports, sports management, leadership, gender, Ebonyi State

\section{Introduction}

Sports, all over the world, has become an established entity that exerts great influence on the social, political and even the economic environments of any nation and that of the individuals. Onifade (2003) defined sports as structured and institutionalized activities that involve vigorous physical exertion and has the components of competition and process on a continuum between play and work. Ihediwa (1997) also described sport as a highly formalized and organized physical activity of high intensity regulated by accepted rules and regulations, which requires maximum physical and/or mental exertion. Sports has become an important aspect of the Nigeria culture so much that the interest and popularity in it has affected the political, social, economic and educational fabric of the nation (Amuchie, 1998). Udoh, (1998) asserted that sports provides employment opportunities to both men and women all over the world. Women develop qualities like co-operation, patriotism, accommodation to solve conflicts, respect for authority and discipline. Through sports, women acquire skills for future use as sports managers and handlers. Sports inculcate selfreliance, obedience to constituted authority, moulding the image of an individual and nation at large (Bucher 1979). However, in order to achieve all these benefits mentioned, sports have to be managed and administered properly.

It is believed that when sports is properly managed and administered, it becomes a powerful builder of character, framework for self discipline and an opportunity to attain highest level of performance. Therefore, sport management is defined as the field of study offering the specialized training and education necessary for individuals seeking careers in any of the many segments of the industry. In the context of this study, sport management means using the acquired skills in human resource management to organize and administer sporting activities. Morakinyo (2000) opined that successful sports management requires the service of a person who has been trained for the job and should not be left in the hands of those who do not know much about sports. Omolawon (2000) also observed that administration of sports succeeds or fails due to the actions of those responsible for managing it because the personnel involved in managing sports programme is a vital factors for successful programming. Therefore, leadership among women is an important but perhaps poorly understood area of sports. Leadership is a complex process by which a person influences others to accomplish a mission, task or objectives and directs the organization in a way that makes it more cohesive and coherent.

The term gender is used when referring to the process of learning the roles of man and woman, boy and girls. According to Hornby (2001), gender is defined as the fact of being male or female. One of the stereotypes of athletic females is that they are masculinized. Sports have been defined as male arena (Olumba, 2009). In Nigeria, women constitute more than half of the population with 50 percent of the wage employment while men have an average participation rate of 95 percent (Akiyode and Afolabi, 2004). Women all over the world face various forms of discrimination which limit their opportunities to develop their full potentials in leadership positive in sports (Adeyanju, 1992). When one walks into a sports council or any sports establishment and glances through the staff roster, in most cases one finds that the number of men occupying leadership positions far exceeds those of the females. Since this occurrence is common, there must be some explanations other than more coincidence. It may be argued that this is true in other jobs but sports related fields seem to out rank them all (Adyanju, 1992).

Female involvement in sports has increased considerably but the majority of the functional positions, and especially those in the top hierarchy of sport establishments, are occupied by men (Adeyanju, 1998). Females are being more or less ignored. This short coming has been evidence and if steps are not taken to correct the anomaly, it may deter the future progress of sports in this country especially in Ebonyi State. 


\section{International Journal of Science and Research (IJSR) \\ ISSN (Online): 2319-7064 \\ Index Copernicus Value (2013): 6.14 | Impact Factor (2014): 5.611}

Although females have been as exposed as men to the general achievement orientation of Nigerian society, they have not been so encouraged to succeed in those areas traditionally defined as male activities. Sports have been traditionally perceived as male domain (Olumba, 2009). He further stated that sports involvement for the male at any level is expected and rewarded; it is perhaps the most visible means for validating the internalization of male sex role. Traditional sports such as local wresting, example, is a laboratory for socializing males for appropriate masculine behaviour in the Nigeria society, whereas females are rewarded for practicing future marital roles (Adeyanju, 2000). This tradition has been very resistant to change and has resulted in sex labeling of jobs. The hiring or appointment of females is frequently governed by traditional attitudes which establish what jobs are suitable for them. Jobs entailing much physical strength for example, soccer, coaching tends to be automatically labeled male (Penheimer, 1995). It is often believed that if females are placed in such jobs, they will not be able to cope and they are likely to produce negative results not only among male colleagues, but also to the public at large. It is generally believed by the society that no matter how highly qualified; a female cannot be as good as a male occupying the same kind of job position.

Johnson (1998) noted that a female, if at all found in high position, has no executive powers simple because she is a female hence, only cosmetic and in order to show who is competent she often exhibits ,male like characteristics in her work. She assumes that she will be tolerated only if she is super-efficient. Since these are out of her traditional role, she faces criticisms or even over hostility, both of which make it more difficult for her to exercise the powers normally associated with her position. If she chooses not to be a mediocre, she ,steps on the toes ${ }^{\text {ee }}$ of those people to whom she is a threat, particularly those men whose desire is a submissive non-aggressive female. In relation to this problem, Okafor (1994)remarked that men are women's problems and that men want to control females in the house as house wives, control them in the professions, and in sports also men wants to lead them "man" all the posts as well as dictate the pace for them.

Finally, it can be seen that the society traditionally is not very kind in its assessment and treatment of females in leadership positions. Amuchie (1998) observed the discrimination and injustice acting upon women ex existence in Nigeria society are manifested and perpetuated in the area of sports management. Ogwa (1997) opined that the United Nations International Women's decade has served as a radical agent in brining into focus the idea that social, economic and political structure and processes in Africa are gendered.

\section{Statement of the Problem}

The challenges of sports administration, and the need for knowledge and development in leadership, have been recognized by both researchers and sports administration in the past few Years (Branch, 1990; McGee, 1984; Soucie, 1996; Wees, 2000; Zenger, 1985). These divergent challenges and competencies are all tending to make athletic administration a unique and complex area of leadership research, and make the study of athletic directors ${ }^{\text {ee }}$ leadership behaviours critical to the effective and efficiency of their respective sports organizations, including those in Ebonyi State. According to Acosta and Carpenter's (2010), most recent examination of women in sport leadership, only $19.3 \%$ of athletic directors are female. As Acosta and Carpenter noted in their study, a female administered $90 \%$ of women's sports programmes while almost no females administered programmes that included men's teams. Most of the female directors of sports had their roots in physical education and often continued to teach while serving as the sports director of women's athletics programme. In Universities today, however, Acosta and Carpenter reported that females represent over 57 percent of the students. The scholars noted that females represent 34.9 percent of the sports administrative staffs, but less than 20 percent of them held sports director position. They added that in 2008, females held almost half of the administrative jobs in athletic departments and now 13.2 percent of athletic programmes have no females anywhere in their administrative structures.

In Ebonyi State, there are many existing sports positions in sports unit but since the creation of Ebonyi State in 1996, there has been no female Director in Ebonyi state Sports Council and other sports establishments (Egba, 2014). Asagba (2005) opined that the percentage of female administrators worldwide in sports councils and even in institutions is $5-10$ percent and is positions of decisionmaking. He went further to say that in bigger sports organizations like the Confederation of African Football (CAF) and Federation of International Football Association (FIFA), their presidents from inception till date had been males. A visit to the sports councils in various states revealed that females have been neglected in terms of assignment of managerial roles despite the increase in participation of women in sports and their ability to excel in wide variety of sporting activities formally considered exclusive to men (Adeyanju, 1992). The administrative and managerial echelon is made up of mostly men where the women folk could compete favourable. Nwankwo (1996) opined that despite the fact that female sports participation had increased at all levels, women had not entered the managerial levels to assume leadership roles. Therefore, the aim of this study is to find out whether gender was the determinants of leadership positions in sports management in Ebonyi State. Information generated in this study will be useful to the government at various levels, sports administrators/managers, organizations, societies, sports bodies, Ministry of Women Affairs and Ministry of Youth and sports to enable them to have an insight as it concern the tapping of various potentials of women in sports administration, management and leadership by avoiding sex role stereotypes which had been a barrier for women's participation in sports management/leadership.

However, the present study was delimited to one of these demographic variables, namely gender. The research therefore was embarked to find out whether to determine how gender perceived as a determinant of leadership positions in sport management in Ebonyi State Nigeria. One hypothesis was postulated in the study as follows: There is

\section{Volume 4 Issue 11, November 2015}




\section{International Journal of Science and Research (IJSR) \\ ISSN (Online): 2319-7064 \\ Index Copernicus Value (2013): 6.14 | Impact Factor (2014): 5.611}

no significant difference in the mean scores of male and female staff in their perception of the determinants of leadership positions in sports management in Ebonyi State.

\section{Theoretical Framework}

This study was based on behavioural theory of leadership. This theory seeks to understand leadership through the behaviour of the people that occupy the position (Fasan, 2000). In this direction leadership behaviour is expected to change as the situation and even the external environment of an organization changes. This theory is more sophisticated and modern as it gives room for change, training and retraining of leaders and followers. Man as a social animal does not exist in a vacuum he needs the relationship and interaction with others to survive. So, whether you are the leader or subordinate you need to change when the situation changes and that is what are called adaptation, and adaptation is a measure of intelligence. Every intelligent being (male or female) is a potential leader. So, this study adopted this theory of leadership called behavioural theory because the skill, training and certificate of a leader will enable him/her to lead the people well at any given situation.

\section{Methods}

This study employed the descriptive survey research design. The study was conducted among 410 (male 308, female 102) staff of sports council and ministry of youth and sports of Ebonyi State, Nigeria. All the entire 410 staff (male and female) was used for this study. This was because the number of persons that constituted the population was of a manageable size, (Nwana, 1992). A self-developed structured questionnaire titled :leadership scale questionnaire (LSQ which consisted of 8 items arranged in two sections; A and B was used as instrument for data collection. Section A, contained 4 items about the personal data of the participants. Section B, consisted of 4 items on gender. It had a 4-point scale which graded the degree of agreement or disagreement as expressed by subjects. Five experts in the Department of Human Kinetics and Health Education, Ebonyi State University, Abakaliki and Department of Science Education of the same University were used in validating the questionnaire. Thirty staff members (both male and female staff) of Ebonyi State University (EBSU) Sports Unit, not included in the main study, were used for test of reliability of the instrument for this study. The data yielded a reliability coefficient of 0.898 using Cronbach alpha. The reliability coefficient was considered high enough for the study based on Ogbazi and Okpalaees (1994) suggestion of 0.60 for good instruments.

Permission was obtained from the administrative heads of the Sports Council and Ministry of Youth prior to data collection. A consent note with the explanation for the research purpose, method of responses and assurance of anonymity was attached with the questionnaire. The researchers administered the questionnaire on the staff (males and females) in their respective offices. The copies of the questionnaire were collected from the staff immediately on completion. This method ensured a 100 percent return rate of the questionnaire.
In analyzing the data collected, the completed copies of the questionnaire were examined for completeness of responses and all the 410 copies of the questionnaire (male 308), (female 102) distributed were successfully completed representing $100 \%$ return rate, and were used for analysis. The responses columns of the questionnaire were allocated scores as follows: strongly agree $(\mathrm{SA})=4$, agree $(\mathrm{A})=3$, disagree $(\mathrm{D})=2$ and strongly disagree $(\mathrm{SD})=1$. The criterion mean of 2.5 was used for the study. It was obtained by adding all the scores assigned to the responses options and dividing the sum by the number of the response options.

Thereafter, Olaitan (1983) criterion adapted from Likertes scaling was applied to categorize the constructs being studied for the purpose of description. A criterion mean $(\bar{x})$ scores of 2.50 and above was adjudgd as the determinants of leadership positions in sports management in Ebonyi State and a mean $(\bar{x})$ score below 2.50 was not adjudged as the determinants of leadership positions in sports management in Ebonyi State. Standard deviation was used to determine how the participant's responses varied while t-test was used to test the hypothesis on gender in order to find out their responses on leadership in Ebonyi State. All data analysis was done with statistical package for Social Sciences (SPSS) version 20.0 for windows.

\section{Results}

\section{Research Question}

What is the perception of gender as a determinant of female leadership position in sports management in Ebonyi State?

Table 1: Mean, standard deviation gender as a determinant of leadership positions in sports management in Ebonyi

\begin{tabular}{|c|c|c|c|c|}
\hline \multicolumn{5}{|c|}{ State } \\
\hline$S / N$ & Items & $\bar{x}$ & $S D$ & Decision \\
\hline 1. & $\begin{array}{l}\text { People believe that management of } \\
\text { sports is better performed by men }\end{array}$ & 3.27 & 1.04 & Agreed \\
\hline 2. & $\begin{array}{l}\text { By virtue of women"s biological } \\
\text { function as child bearers, women } \\
\text { are viewed as not being very good } \\
\text { for other roles except child-rearing. }\end{array}$ & 2.15 & 1.07 & Disagreec \\
\hline 3. & $\begin{array}{c}\text { The society perceives women as } \\
\text { fragile and delicate and therefore } \\
\text { should not be allowed to be } \\
\text { involved in leadership especially in } \\
\text { sports setting. }\end{array}$ & 2.62 & 1.04 & Agreed \\
\hline 4. & $\begin{array}{l}\text { Women perceived sports profession } \\
\text { as belonging to men alone. }\end{array}$ & 2.55 & 1.12 & Agreed \\
\hline & \begin{tabular}{c|} 
Grand mean \\
\end{tabular} & 2.65 & 0.67 & Agreed \\
\hline
\end{tabular}

Table 1 shows that all the items (except item 2) obtained mean scores of 2.50 with grand mean of 2.65 and SD of 0.67 . This indicates that the respondents agreed that gender was a determinant of female leadership position in sports management by their responses on items 1, 3 and 4 whereas on item 2 , the respondents disagreed that gender was not a determinant of female leadership positions in sports management 


\section{International Journal of Science and Research (IJSR) \\ ISSN (Online): 2319-7064 \\ Index Copernicus Value (2013): 6.14 | Impact Factor (2014): 5.611}

\section{Hypothesis}

There is no significant difference in the perception of determinants of female leadership position in sports management in Ebonyi State by gender.

Table 2: Mean, standard deviation and t-test value on the perception of male and female staff on gender as a determinant of leadership positions in sports management in Ebonyi State

\begin{tabular}{|c|c|c|c|c|c|c|c|}
\hline Variables & $\mathbf{N}$ & $\bar{x}$ & SD & t-cal. & df & t-tab. & Dec. \\
\hline \multicolumn{8}{|c|}{$\begin{array}{l}\text { Perception of gender as a determinant of female leadership } \\
\text { position in sports management }\end{array}$} \\
\hline \multirow{2}{*}{ Male } & 308 & 2.71 & 0.65 & & & & \\
\hline & & & & 3.39 & 408 & 1.96 & $\mathrm{~S}$ \\
\hline Female & 102 & 2.45 & 0.71 & & & & \\
\hline \multicolumn{8}{|c|}{$\begin{array}{c}\text { Perception of age as a determinant of female leadership position } \\
\text { in sports management }\end{array}$} \\
\hline \multirow[t]{2}{*}{ Male } & 308 & 2.87 & 0.48 & & & & \\
\hline & & & & 0.06 & 408 & 1.96 & $\mathrm{NS}$ \\
\hline Female & 102 & 2.85 & 0.48 & & & & \\
\hline \multicolumn{8}{|c|}{$\begin{array}{l}\text { Perception of level of education as a determinant of female } \\
\text { leadership position in sports management }\end{array}$} \\
\hline \multirow[t]{2}{*}{ Male } & 308 & 3.18 & 0.58 & & & & \\
\hline & & & & 0.73 & 408 & 1.96 & NS \\
\hline Female & 102 & 3.13 & 0.76 & & & & \\
\hline \multicolumn{8}{|c|}{$\begin{array}{c}\text { Perception of work experience as a determinant of female } \\
\text { leadership position in sports management }\end{array}$} \\
\hline \multirow[t]{2}{*}{ Male } & 308 & 2.45 & 0.63 & & & & \\
\hline & & & & 1.46 & 408 & 1.96 & NS \\
\hline Female & 102 & 2.57 & 0.83 & & & & \\
\hline
\end{tabular}

Key: $\mathrm{S}=$ Significant $(\mathrm{p}<0.05)$; NS = Not Significant.

Table 2 shows the responses of male and female respondents on their perception of gender as a determinant of female leadership positions in sports management. The result showed a calculated $t$ - value of 3.39 which is greater than the table t-values of 1.96 at 0.05 level of significance. This indicated that there was a significant difference in the perception of male and female staff respondents on gender as a determinant of female leadership positions in sports management. Thus the hypothesis was rejected. The case was different on their responses in age, level of education and work experience as determinants of male and female staff leadership positions in sports management.

In these three areas, the analysis of the responses of male and female staff agreed with the hypothesis that there is no significant difference on the respondents of male and female staff in their perceptions of determinants of female leadership positions in sports management. Statistically, the calculated value of 0.06 was less than the table value of 1.96 in respect to age. Similarly on level of education, the calculated value of 0.73 was less than the table value of 1.96. This suggests that their perception based on age and level of education was not significant. The same applies to work experience where the calculated value of 1.46 was less than the table value of 1.96. By this, the analysis indicated that the null hypothesis which states that there is no significant difference based on gender was rejected, despite the results of individual items in the cluster.

\section{Discussion}

Data in table 1 revealed that male dominance contributed to low female leadership position in sports management. This finding is in line with Olumba (2009) who asserted that sports has been traditionally perceived as male domain, and that sports involvement for the male at any level is expected and rewarded. It is perhaps the most visible means of validating the internalization of male sex role. Adeyanju (2000) opined that the issue of male dominance is both a socializing and structural force and it exist at interactions of women and men, to the patterning of gender bias that is found in all cultural forms and institutions which has resulted to the sex labeling of jobs. The findings tend to be in line findings of Asagba (2005) who reported that male dominance has been notable in the administrative and leadership branches of sports where men have clearly over shadowed women in power and number. He further stated that among sports administrators, the percentage of female administrators worldwide in sports councils and even in institutions is between 5-10 percent and the same for positions of decision making 2-10 percent. Even in bigger sports organizations like the Confederation of African Football (CAF) and Federation of International Football (FIFA), their presidents from inception till date had been males.

Furthermore, it was observed that there was significant difference between male and female staff in their perception of the determinants of leadership positions in sports management in Ebonyi state. This finding is in agreement with the view expressed by Okafor (1994) that men are women s problems and that men want to control females in the house as house wives, control them in the professions and in sports also men want to lead them ,Man ${ }^{\text {ee }}$ all posts as well as dictate the pace for them. Penheimer (1995) explained that the cause of low female absence in leadership positions is the traditional attitude which established that jobs entails much physical exertion, for example soccer coaching, tends to be automatically labeled male. He further stated that it is often believed that if females are placed in such jobs, they will not be able to cope and they are likely to produce negative results not only among colleagues but also in the public at large. However, it is generally believed by male that no matter how highly qualified, a female cannot be good as a man occupying the same kind of jobs positions because men are task oriented while women are people oriented. This can be seen in Ebonyi state that since the creation of Ebonyi State no female was involved in sports leadership (Egba, 2014).

\section{Conclusion and Recommendation}

The findings of the present study provide evidence that women had been neglected in all aspects of leadership positions in sports management in Ebonyi State based on gender. The study has contributed to the accumulation of data on the determinants of leadership positions in sports management. It was suggested that research be conducted in other states in Nigeria to find out whether the same pattern exist. Therefore, Government, sports bodies and organizations should include women in the policy and decision making bodies in sports in order to reduce male dominance. 


\section{International Journal of Science and Research (IJSR) \\ ISSN (Online): 2319-7064}

Index Copernicus Value (2013): 6.14 | Impact Factor (2014): 5.611

\section{References}

[1] Acosta, R.V., and Carpenter, L.J. (2010). Women in intercollegiate sport: A longitudinal study-twenty-five year update, 1977-2002. Brooklyn, NY: Brooklyn College, Department of Physical Education.

[2] Adeyanju, F.B. (1998). Nigeria women and sports participation. Stereotypical misconception, reality and future projections in psycho-social perspectives. Maiduguri: Fourth Dimension Publishers Limited.

[3] Adeyanju, F.B (2000). Women and sports particiation.21st century and sports development in Nigeria. Abuja: Federal Ministry of Sports and Social Development, pp. 195-205.

[4] Adeyanju, F.B. (1992). Female leadership role: Implementation per sports development in Nigeria. Paper Presented at the Multi-Dimensional Perspective of Women Participation in Sports, Organized by (NAWIS) Kaduna.

[5] Akiyode, I.O., and Afolabi, K. (2004). Sports administration towards the enhancement of the Nigeria sport programmes. 5th NAPHER Conference Proceedings. University of Ife, Ile-Ife, August.

[6] Amuchie, F.A. (1998). Nigerian women and sports participation and alternatives. ABUPHERI, p. 1.

[7] Amuchie, F.A. (1998). The relationship between transformation leadership behaviour of athlete directors and coaches job satisfaction. The Physical Educator, 55(4), 170-175.

[8] Asagba, B.O. (2005). More than a match: The struggle for gender equity in sports. Faculty lecture series No.11 Faculty of Education, University of Ibadan, Ibadan.

[9] Branch, D. (1990). Athletic director leader behaviour as a predictor of intercollegiate athletic organizational effectiveness. Journal of Sport Management, 4, 161173.

[10]Bucher, C. A. (1979). Administration of physical education and athletic programmes. St. Louis: The C.V. Mosby Company Ltd

[11]Ebonyi State Sports Council, Abakaliki (2011). Nominal roll of male and female staff in Ebonyi State Sports Council and Ministry of Youth and Sports. Abakaliki: Ebonyi State Sports Council, Abakaliki.

[12] Egba, N.A.(2014). Demographic determinants of female leadership positions in sports management in Ebonyi State. Published Masters Dissertation, Ebonyi State University, Abakaliki.

[13]Fasan, C.O. (2000). Sports business management. Gaithersburg, MD: Aspen Publishers.

[14] Hornby, A.S (2001). Oxford advanced learner's dictionary of current English. New York: Oxford University Press.

[15] Hornby, J.C. (2001). New leadership 101: Inspirational quotes and insight for leaders. Benin-city, Nigeria: Mathew Christian Publications.

[16] Ihediwa,U.C. (1997). Legal considerations towards effective sports management. In National Institute of Sports (Ed.), Effective management and marketing of sports in Nigeria Vision 20: 2020. Lagos: National Institute of Sports.

[17] Johnson, W. (1998). Inferiority of female athletes: Myth or reality. Journal of Sports Medicine, 5, 215-219.
[18] McGee, M. (1984). Management approach: Training athletic directors. Athletic Administration, 19(1), 20-21.

[19] Morakinyo, E.O. (2000). The female athlete: A coach's guide to conditioning and training. St. Louis: The C.V. Mosby Company.

[20] Nwana, O.C. (1992). Introduction to educational research. Ibadan: Heinemann educational Books (Nig.) Ltd.

[21] Ogbazi, J.N., and Okpala, J. (1994). Writing research reports: Guide for researching in educational, social sciences and humanities. Owerri: Prince Time Series.

[22] Ogwu, T.N. (1992). Education and problems of women's participation in sports: Paper presented the first multi-dimensional perspective of women participation in sports, organized by (NAWIS) Kaduna.

[23] Okafor, U. (1994). Faculty concept on the masculinity and anti-conception theories about women in sports. JOPHHER, ALUANA, 1, 22-27.

[24] Olaitan, S. (1983). Factors associated with nonutilization of hospital services for antenatal care by pregnant women in rural communities of Anambra State of Nigeria. In O. S. Okobiah, A. Ali and G. B.I. Onuoha (Eds.), Occasional publication of Institute of Education, University of Nigeria, Nsukka (No. 4, pp.65-70). Nsukka: Institute of Education, University of Nigeria.

[25] Olumba, M.O. (2009). Sociology of Sports for degree classes. Enugu: Iyke Ventures Production.

[26] Omolawo, K.O. (2000). Parameters influencing the propagation of physical education and sport programmes in Nigeria schools. Proceeding of the 1st ICHPER-SD Africa regional Conference, pp. 37-40.

[27] Onifade, M.D. (2003). The role of sports in national development. NAPHER.SD Monograph Series, 2(1), 105-112.

[28] Penheimer, V.K. (1995). The sex labeling of jobs. In M.T. Mednick, S.S. Tanger, and L.W. Hoffman (Eds.), Women and achievement: Social and motivational analyses. New York: John Wiley and Sons.

[29] Soucie, D. (1996). Effective managerial leadership in sport organizations. Journal of Sport Management, 8, 113.

[30]Udoh,C. O.(1998). Participation of youths in sports: Health benefits derivable there from. A keynote address delivered at the $12^{\text {th }}$ conference of the Nigerian association for sports science and medicine (NASSM), Oyo, Nigeria.

[31] Weese, W.J. (2000): Research note: Are executive leaders in sport as good as they think? European Journal for Sport Management, 7(2), 65-76.

[32]Zenger, J.H. (1985). Leadership: Management's better half. Training, 22(12), 44-53. 